\title{
ICT uses in education. Theoretical framework proposal for its characterization and analysis
}

\section{El uso de las TIC en la educación. Propuesta de marco teórico para su caracterización y análisis}

\author{
MARTÍNEZ-MARQUEZ, Marco Antonio †* \\ Universidad de Guadalajara, Mexico.
}

ID $1^{\text {st }}$ Author: Marco Antonio, Martínez-Marquez / ORC ID: 0000-0003-2898-6687, Researcher ID Thomson: S-76412018, PubMed Autor ID: 6389e65a779dbab5d5a321412226c3915f08, CVU CONACYT ID: 825933

DOI: $10.35429 /$ JSEM.2021.22.8.16.23

Received January 15, 2021; Accepted June 30, 2021

\begin{abstract}
It is clear that during the last few decades, ICT use has considerably increased in education, and it has intensified over the last year as a consequence of an online approach because of the health emergency caused by COVID-19. Nevertheless, despite of the efforts made by schools for keeping updated on the technological equipment and the multiple teacher training processes on this subject, results has not been as expected. This is demonstrated by the higher grade-failure and school drop-out. In this regard, this work aims to propose a theoretical framework to guide characterization and analysis processes on the use of ICT in education. The above, form Vygotsky's sociocultural theory of human learning, which favors the social construction of learning, but also, from Edgar Morán's complex thought theory, who prioritizes pertinent thought for social problem solving. And, finally, from online education psychology, where Cesar Coll and Carles Monereo stresses the importance of building working environments that promotes meaningful learning. This work aims to offer a reference framework for the case study, for implementation of improvement processes in favor of the students.
\end{abstract}

Education, ICT, Use, Characterization, Theoretical framework

\begin{abstract}
Resumen
Es evidente que durante las últimas décadas el uso de las TIC se ha incrementado considerablemente en el ámbito educativo, intensificándose el último año, como consecuencia de la implementación de una modalidad en línea, ocasionada por la contingencia satinaria provocada por la COVID-19; sin embargo, pese a los esfuerzos realizados en las escuelas por mantenerse actualizadas en cuanto a equipamiento tecnológico y los múltiples procesos de capacitación docentes en esta materia, los resultados no han sido los esperados, así lo demuestran los altos índices de reprobación y descerción escolar; en este sentido, en el presente trabajo se plantea una propuesta de marco teórico para orientar procesos de caracterización y análisis del uso de las TIC en educación, lo anterior, desde la teoría sociocultural del aprendizaje humano de Vygotsky, que privilegia la construcción social del aprendizaje; también desde la teoría del pensamiento complejo de Edgar Morán, que prioriza el pensar pertinente para la resolución de problemas sociales; y, finalmente, desde la Psicología de la educación virtual, donde César Coll y Carles Monereo destacan la importancia de construir entornos de trabajo que promuevan el aprendizaje significativo. El trabajo tiene como finalidad ofrecer un marco de referencia para el estudio de casos, que permita implementar procesos de mejora en beneficio de los alumnos.
\end{abstract}

Educación, TIC, Uso, Caracterización, Marco teórico

Citation: MARTÍNEZ-MARQUEZ, Marco Antonio. ICT uses in education. Theoretical framework proposal for its characterization and analysis. Journal of Systems and Educational Management. 2021. 8-22:16-23.

*Correspondence to Author (Email: licmarco@cunorte.udg.mx)

$\dagger$ Researcher contributing as first Author. 


\section{Introduction}

Although it is true that for at least a couple of decades there has been a very marked trend towards the use of information and communication technologies in education, seeking innovation in teaching processes and improvement of learning processes, based on In the excellent results that have been achieved with its incorporation into other social areas, such as industry, it is no less true that this has been catapulted during the last year, as a result of the health contingency caused by COVID-19, and that, according to the policy report "Education during and after COVID-19", issued in August 2020 by the United Nations (UN; 2020), has caused the greatest interruption of the history in education systems, affecting $94 \%$ of students worldwide.

The foregoing, and also according to the UN (2020), has aggravated the pre-existing educational disparities, leaving those who have less opportunities without opportunities, and this is demonstrated by the high rates of reprovation and descent that educational institutions begin to report, about all those of medium and higher level, making it clear that what was said in this regard by various authors, years ago, is still valid, such as that the use of ICT in schools is peripheral and marginal, and that its imposition, when it is in Against the culture of an educational institution, it does not give the expected results, since teachers end up schooling innovations (Cuban, 1993); that it is practically impossible for schools to keep up with the accelerated pace of technological changes and with it the literacy of teachers (Edel; 2010); and that, today more than ever, new spaces and opportunities for learning must be built, such as e-learning, but redefining the roles of teachers and students, as well as the processes they carry out (Benabides and Pedró; 2007).
Current conditions then force us to think that perhaps education should not go back to being the same as before, and that for its own sake and that of the students, it should not return to "normality", but rather that it has to be rethought based on the needs imposed by the modern world and the potential that ICTs have to innovate the work of teachers and improve student learning, which forces those who carry out research in education, to characterize and analyze how the use of technological tools in this area during the last year, to be in a position to propose concrete improvement actions, which is not always easy if you do not have a frame of reference to carry out such research.

In this sense, this work presents a proposal for a theoretical framework that helps guide the efforts that are beginning to take place to measure the reality of education in times of the pandemic caused by COVID-2019, based on the statement that:

"We do not go to reality as a blank slate, we
read it from our ideological and scientific
perspective... social events and phenomena
are not presented as flowers to be picked. It is
necessary to know how we are going to orient
ourselves to collect the data, facts and
phenomena that occur in social reality. This is
precisely the role of the theoretical framework:
to guide the research process". (Ander-Egg;
1993: 154).

The theoretical framework, as a guiding element in a research process is, in the words of Ander-Egg (1993), the space where general and specific theoretical propositions are expressed, as well as the postulates, assumptions, categories and concepts that help as reference to the researcher, so that he can order the facts that make up the problem under study; adds the author, that even when the facts or social phenomena that are observed in reality, are the raw material to carry out a scientific investigation, one must be aware that it is not enough to observe them, identify them, collect them and interpret them in a way Empirical, on the contrary, there must be a general orientation, supported by theory, that proposes how to do it. 
Two issues that must be borne in mind, according to the cited author, are: on the one hand, although the choice of the theoretical framework is an a priori decision, it must be done carefully, since it depends on whether the answer to the problem posed is the adequate or not; and on the other, that a theoretical framework cannot be abused in its empirical use, the application of the categories of analysis beyond the contexts for which they are valid should be avoided.

\section{Theoretical alternatives for the analysis of the use of ICT in education, with the aim of achieving its characterization}

Precise general aspects regarding the concept of theoretical framework, its importance as a guiding element in solving a research problem and the care that must be taken when choosing and using it, it is time to present a concrete proposal, through theoretical alternatives that allow the characterization and analysis of the use of ICT in education.

\section{A) Sociocultural theory of human learning}

"Each of the functions in cultural development ... appears twice: first, at the social level, and then, at the individual level; first, between people (interpsychological), and then within ... (intrapsychological). This applies to both voluntary attention and logical memory and concept formation. All higher functions originate as true relationships between individuals." (Vygotsky; 1978, taken from UNESCO; 2004: 31).

The sociocultural theory of human learning by Vygotsky (1978, cited by UNESCO; 2004), is an important reference to interpret the facts or phenomena object of an investigation on the use of ICT in education, the central elements that this theory contributes are the following:

- Learning is a social process, which takes place on two levels: first, through the interaction of one person with others; and second, in the integration of knowledge to the mental structure of each individual.

- The potential for cognitive development lies in the zone of proximal development, an area of exploration for which the student is cognitively prepared, but which requires support and social interaction.
- A teacher or a student with more experience, can provide another student with the scaffolding for the development of understanding of knowledge or complex skills.

From what has been said, we can see the importance of the social in the development of individual cognition, of work on the zone of proximal development, to take a subject from one cognitive level to another, and of the supportive scaffolding that can be provided among peers. to understand knowledge or acquire skills.

Now, it is clear that this has occurred throughout history without the use of ICT, and in practically all educational institutions whose modality has been face-to-face or mixed in recent years; However, the challenge today is how to achieve this social interaction, through technological resources; that is, social environments, directed by teachers, contribute to the development of individual cognition of students, on which UNESCO, based on this theory, affirms:

ICTs can be used to support this learning environment [socially rich environments] by serving as tools to promote dialogue, discussion, collaborative writing and problem solving, and by providing online support systems to underpin progress in learning. understanding of students and their cognitive growth. (UNESCO; 2004: $31)$.

From the above it follows that:

- Knowledge is not an element with autonomy and meaning apart from the subjects who learn, it is a permanent construction that makes sense based on their conditions and their context.

- Knowledge is not transmitted as a product, it is the result of a process of acquiring new meanings.

- You should always start from the students' previous knowledge, as they are the basis for contextualizing learning and making it meaningful. 
- Relevant educational actions, contextualized and loaded with content and significance, should be promoted through conducive environments that transfer the emphasis of teaching-learning from the teacher to the students.

- The generation of knowledge should be promoted according to the needs of the environment.

From this approach, the implementation of collaborative work should be promoted, where students carry out activities that allow them to build knowledge, first in the social sphere, and then individually, that is significant for them, contributes to their professional training, and to the solving problems of the environment; this, in diverse and flexible learning environments, allowed thanks to the use of technologies.

Thus, generating socially rich learning environments, to promote interaction between people, then the integration of knowledge to the mental structure of students, acting on their zone of proximal development and providing them with the necessary scaffolding for understanding, but also for the acquisition of Complex skills, through the use of ICT, is a first reference element to guide a research process on the use of technologies in education.

\section{B) Complex thought theory}

"Complexity is ... the fabric of events, actions, interactions, feedbacks, determinations, hazards, that constitute our phenomenal world ... complexity is presented with the disturbing features of the entangled, the inextricable, of disorder, ambiguity, uncertainty ... Hence the need for knowledge to put order in phenomena by rejecting disorder, to discard the uncertain, that is, to select the elements of order and certainty, to remove ambiguity, clarify, distinguish, rank." (Morán; 1998: 32).
A second element for the integration of a referential framework and from which the facts object of an investigation on the use of ICT in education can be explained, is Morán's theory of complex thought (1998), where it is discussed complexity as what is woven together, and that, in that sense, the great challenge for educational institutions today consists of intertwining the parts with the whole, having as an aspiration to relate, at different levels, the school with its environment, and with the reality that they are having to live, associate ideas with existing problems, and relate disciplines to address social conflicts from an inter-multi-transdisciplinary approach.

Based on the above, it is suggested that the challenge of learning based on complex thinking is the challenge of pertinent thinking, which must be understood as thinking that relates and articulates ideas based on their applications in daily life. It is also stated that the association between ideas and their practical application seeks to reconcile the disjunction between experience and reason. (Morán; 1999).

Thus, one of the main elements of academic models today is to promote the association of the knowledge obtained by students, with their immediate social environment and their reality, through learning based on problems, projects and case analysis.

This last part will be relevant for the analysis of problems detected with the use of ICT in the teaching-learning processes, especially when it is sought, in practically all educational institutions, a coherent articulation between disciplines, which allows the approach of the existing problems in the environment through an inter-multi and transdisciplinary approach, starting from the need to recognize that knowledge can be divided into disciplines, but reality cannot, so it seeks to overcome the tendency that currently exists to fragmenting knowledge, promoting the necessary conditions for the generation of multidimensional knowledge, which can establish links between the different areas of knowledge, to address in a pertinent way the problems that exist in a given context. 
In conclusion, to know the way in which, through the use of technologies, teachers promote pertinent thinking; that is, articulating knowledge with the problems of an environment, in order to find viable solutions to them, in an inter, multi and transdisciplinary way, is another referential element in an investigation.

\section{C) Psychology of virtual education}

"The mediating capacity of ICT as psychological instruments is a potential that, as such, becomes effective or not, and becomes effective to a greater or lesser extent, in the educational practices that take place in the classrooms depending on the uses that the participants make of them. " (Coll et al; 2011: 85).

A third alternative for the characterization and analysis of the use of ICT in education comes from the psychology of virtual education, where Coll et al (2011) have stated, as a result of the incorporation of technological tools into formal educational systems, that the argument to continue believing in the technology-education relationship, and in the potential of the former to innovate the training processes of students, despite the results obtained up to this moment, is that digital resources can really become tools that encourage students to develop skills to think, feel and act alone and with others.

The importance of the above, then, lies in identifying to what extent teachers, recognizing the potential of information and communication technologies, have the skill to use them in a way that guides their students in carrying out both collaborative training activities as individuals.

The previous argument is supported in turn, according to the aforementioned authors, in that technologies give users real possibilities to search for information, access it, represent it, process it, transmit it and share it; but they add, that for this to happen, and in their case, to a greater or lesser degree, it again depends on the role played by each teacher; namely:
The novelty of the new ICTs ... does not lie in their nature as technologies "for" information and communication ... rather, it resides in the fact that ... they allow the creation of environments that integrate known semiotic systems and extend the human capacity to (re) present, process, transmit and share large amounts of information with less and less space and time limitations, almost instantaneously and at an ever lower economic cost. (Idem: 84-85).

As can be seen, once a first problem of access to technologies by teachers and students has been solved, the use made of them will determine if they are really innovating and to what extent and, without any room for doubts, the greater responsibility remains in the hands of the teacher.

The aforementioned authors also point out that it should not be forgotten that ICTs only constitute psychological instruments, when their semiotic potential is used by teachers and students to carry out planning, regulation and orientation activities, Well, in his concept, that is precisely what introduces modifications in the intra and inter-psychological processes that are involved in teaching-learning.

In conclusion, planning, regulating and guiding one's own activities and those of others, creating environments that integrate semiotic systems and expand the capacity of the actors involved, to, with less space limitations, more quickly and with lower costs, promote search, access, represent, process, transmit and share information, in order to develop in students skills to think, feel, act alone and with others, through technologies, is a third referential element that can guide an investigation on the use of ICT in education.

\section{Typology of ICT uses}

“... Established and justified the principle that the effective uses that teachers and students make of ICT depend both on the technopedagogical design of the teaching and learning activities in which they are involved, and on the recreation and redefinition they carry out of the procedures and norms of use of the tools included in this design, it is appropriate now that we return to the question of how we can identify and describe these uses." (Idem: 87). 
It enriches the proposal made by Coll et al $(2011)^{1}$, the possible categories of use of ICT in education, and which is of the following tenor:

Information and communication technologies as mediating instruments between teachers and content. The purpose is to help search, select and organize content.

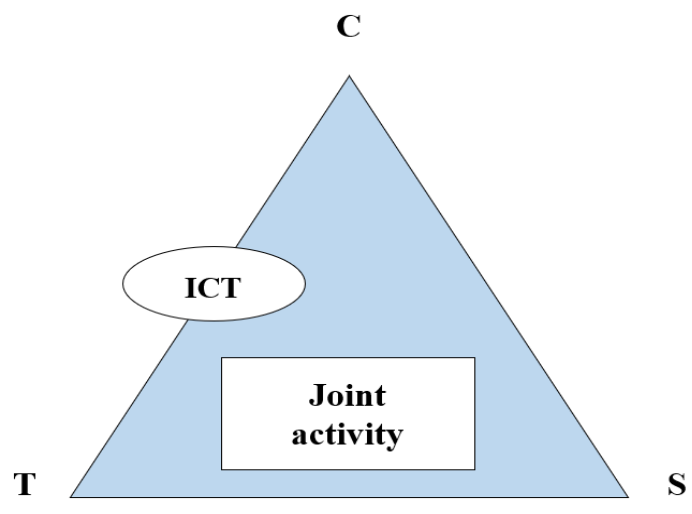

Figure 1 Category 1

ICT as mediating instruments between teachers and students. The objective is to help maintain communication between the process actors.

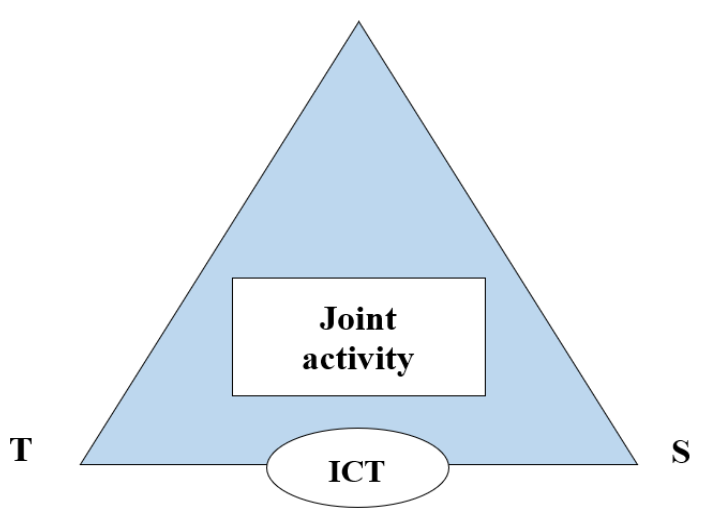

Figure 2 Category 2

ICT as mediating instruments between students and content. In order to allow them to explore, deepen, analyze, assess and choose content.

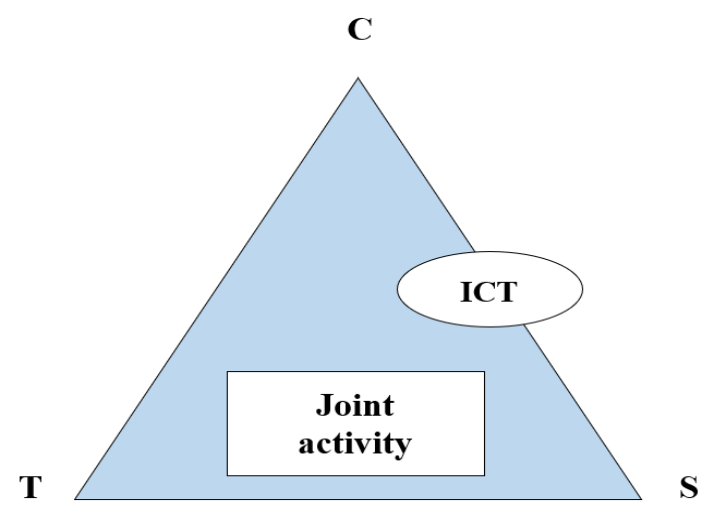

Figure 3 Category 3

ICT as instruments of the joint activity of teachers and students in the realization of teaching-learning activities. Technologies are an amplifier of activities.

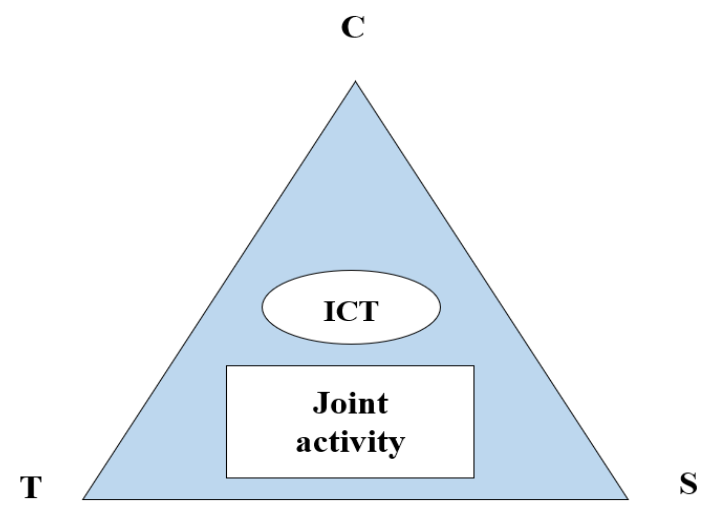

Figure 4 Category 4

ICT as instruments that configure work and learning environments. The purpose is to create individual and collective work spaces, and other parallel ones that promote autonomous and collaborative learning.

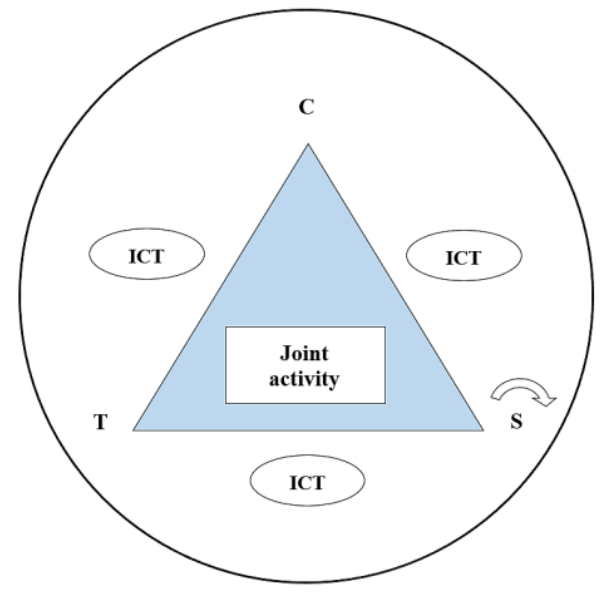

Figure 5 Category 5

\footnotetext{
${ }^{1}$ Typology proposed by Coll C., Mauri T. and Onrubia J., in the book chapter entitled: "The use of information and communication technologies: From techno-pedagogical design to practices in use". In Coll César and Carles Monereo (Coordinators) (2011). "Psychology of virtual education". Edited by Morata, second edition. Spain. Pp. 91, 92.
}

MARTÍNEZ-MARQUEZ, Marco Antonio. ICT uses in education. Theoretical framework proposal for its characterization and analysis. Journal of Systems and Educational Management. 2021 
In general terms, it is a typology, according to its authors, where it is considered that it is in types four and five where the potential of ICT to modify and improve educational practices is most intensely manifested.

Finally, the proposed typology can be considered as a frame of reference for the characterization and analysis of the use of ICT in a specific case, defining in which Category they are located; at the same time, it will be useful for the construction of a proposal that allows improving said use for the benefit of teachers and students, being necessary to evaluate, provide feedback and adjust the processes as many times as necessary, in search of approaching the ideal categories.

\section{Conclusions}

Undoubtedly, the health emergency caused by COVID-19 has come to modify the way we interact, and with it, all social activities, especially those of an educational nature, passing in most cases of the modality traditionalface-to-face to online mode, supported by the use of ICT; However, in a very short time it has been possible to see the damage that this has caused and whose tip of the iceberg is the high rates of school failure and dropout, especially at the middle and higher level, urging researchers to carry out case studies on the use that has been given to technological tools to carry out the teaching-learning processes, which help in decision-making to lessen the impact of the change that the educational system has had, for which in this work we do the proposal of a theoretical framework to guide the work.

The theoretical framework is one of the most important elements in a research process, as it is the space in which the theoretical propositions that will guide the process of collecting data, facts or phenomena that have been identified in a study are made explicit. given context and constitute a problem or point of tension, because even when these are considered the raw material within a scientific study, the truth is that in order to analyze and interpret them, a general orientation must be counted, supported by theory, that propose how to do it and avoid empirical interpretations; therefore, the construction of the theoretical framework must be careful, to guarantee that the answer to the detected problem is adequate.
Thus, when what is intended is the characterization and analysis of the use of information and communication technologies in education, a theoretical framework proposal can be made up of the following propositions:

From constructivism, which proposes the realization of diagnostic tests by rescuing the students' previous knowledge, the generation of a cognitive conflict in it, and then taking it to another level of understanding, helps in the interpretation of the sociocultural theory of human learning from Vygotsky (1978), who establishes that learning is a process of social construction, which occurs first in an interpsychological and then intra-psychological; and, in this sense, the elements to be located in the practices in the use of ICT, would be the capacity of teachers to, through them, generate socially rich learning environments, which promote interaction between students, and then the integration of knowledge to their mental structures, acting on their zone of proximal development and allowing them to acquire complex skills; also determining, according to Coll et al (2011), to what extent teachers are able to plan, regulate and guide the activities necessary for students to seek, access, represent, process, transmit and share information, developing their possibilities of think, feel and act alone and with others.

A second theoretical proposition, for data analysis, is found in the theory of complex thinking and its scope by Edgar Morán (1998), under which the objective is to measure the way in which teachers promote, also through the use of the technologies, the pertinent thinking; that is, if they generate, and to what extent, the ability of students to articulate knowledge with the problems of the environment, in search of viable solutions, and in an inter, multi and transdisciplinary way.

For the above, use can be made of the typology proposed by Coll et al (2011), from which it is considered that ICT in education should be ideally used to configure socially rich work and learning environments that promote learning. collaborative and autonomous.

\section{References}

Ander-Egg, Ezequiel. (1993). “Técnicas de Investigación Social". Editado por Magisterio del Río de la Plata, 23 edición. Argentina. 
Benavides, Francisco y Pedró Francesc. (2007). "Políticas Educativas sobre Nuevas Tecnologías en los Países Iberoamericanos". En Revista Iberoamericana de Educación, número 45, pp. 19-69.

Coll C., Mauri T. y Onrubia J. (2011). "La utilización de las tecnologías de la información y la comunicación: Del diseño tecno-pedagógico a las prácticas en uso". En Coll César y Carles Monereo (Coordinadores). "Psicología de la Educación Virtual". Editado por Morata, segunda edición. España.

Cuban, Larry. (1993). "Computers Meet Classroom: Classroom Win". Tomado de http://sdexter.net/xyz/CompMeets\%20Classroo m.pdf

Edel, Navarro Rubén. (2010). "Entornos Virtuales de Aprendizaje. La contribución de lo virtual en la educación". En Revista Mexicana de Investigación Educativa, volumen 15, número 44, enero-marzo 2010, pp. 7-15. Editada por el Consejo Mexicano de Investigación Educativa. México.

Morán, Edgar. (1998). "Introducción al pensamiento complejo". Editado por Gedisa. España.

Morán, Edgar. (1999). "Los 7 saberes necesarios para la educación del futuro". Editado por la Organización de las Naciones Unidas para la Educación, la Ciencia y la Cultura. Francia.

ONU. (2020). "Informe de políticas: La educación durante la COVID-19 y después de ella".

UNESCO. (1998). "Conferencia Mundial sobre la Educación Superior. La Educación Superior en el Siglo XXI". Editado por la UNESCO. Francia.

UNESCO. (2004). "Las Tecnologías de la Información y la Comunicación en la Formación Docente. Guía de Planificación". Editado por la UNESCO. Francia.

UNESCO. (2005). "Hacia las Sociedades del Conocimiento. Informe Mundial de la UNESCO”. Editado por la UNESCO. Francia. 